\title{
Approaches to Improve Streetscape Design in Saudi Arabia
}

\author{
Abdullah Addas ${ }^{1}$, Ghassan Alserayhi² \\ ${ }^{1}$ Department of Landscape Architecture, Faculty of Architecture \& Planning, King Abdulaziz University, Jeddah, Saudi Arabia \\ ${ }^{2}$ Department of Architecture and Planning, College of Engineering, King Khalid University, Abha, Saudi Arabia \\ Email: aaddas@kau.edu.sa,gmalserayhi@kku.edu.sa
}

How to cite this paper: Addas, A., \& Alserayhi, G. (2020). Approaches to Improve Streetscape Design in Saudi Arabia. Current Urban Studies, 8, 253-264. https://doi.org/10.4236/cus.2020.82014

Received: May 5, 2020

Accepted: May 31, 2020

Published: June 3, 2020

Copyright (c) 2020 by author(s) and Scientific Research Publishing Inc. This work is licensed under the Creative Commons Attribution International License (CC BY 4.0).

http://creativecommons.org/licenses/by/4.0/

\begin{abstract}
The kingdom of Saudi Arabia is looking to enhance the quality of life in its cities by making the cities livable places. This study focuses on the changes that need to be made to the street design in Saudi Arabia to achieve the goals of the 2030 vision. This paper highlights the importance of aesthetics, accessibility, security and safety and walkability, which needs to be considered during street design. The analytical study uses examples from around the world of applying the basic principles of streetscape design in order to develop the streetscape approaches and recommendations in Saudi Arabia. The research emphasizes the importance of developing the urban environment visual image in the country to enhance the quality of life of both people and the city. Approaches include directing urban planners and designers to the important role of the well-designed streetscape and identifying methods of applying sustainability to streetscape design and making street pedestrian-oriented.
\end{abstract}

\section{Keywords}

Quality of Life, Street Design, Streetscape, Value, Wellbeing, Saudi Arabia

\section{Introduction}

Since the 1970s, the kingdom has faced rapid urban expansion in size and population because of massive economic growth, and this has affected the environmental and social aspects of Saudi cities (Addas, 2018). However, with the country's 2030 vision, major programs are being developed to achieve the country's goals of enhancing and improving quality of life in the cities. While these programs are of great value and are focused on major issues in the country, there is a range of substantive issues that play a critical role in enhancing the quality of life. In particular, the design of streets in the country is neglected as can be seen 
in Figure 1 in terms of the pattern of use and quality of the design and as many studies have identified the issue of the streetscape design in Saudi Cites (Rahman \& Nahiduzzaman, 2019; Almahmood et al., 2018; Badawi, 2017).

The Ministry of Municipal and Rural Affairs (MoMRA) is responsible for the provision of the streets and has published a set of guidelines. However, these guidelines have neglected the quality and value of the streets as vital open spaces in the cities (Izenberg \& Fullilove, 2016; Moreland-Russell et al., 2013; Smith et al., 2010). Instead, the guidelines focus only on automobiles and treat streets as being for cars only. This focus has led to a major dependency on cars, especially given the lack of public transportation until recently. In addition, the focus on the automobile has affected residents' wellbeing by increasing obesity and has affected social cohesion and interaction. Furthermore, the lack of well-designed streets that include soft elements, such as planting, could also expose Saudi cities to becoming urban heat islands (Spellman, 2008; Watkins et al., 2007).

This paper looks at Jeddah city street types and aims to create a clear image of the current status of street design in the city, which could be applied to the majority of the streets in the country. In addition, the paper highlights the main approaches that need to be considered in improving the value and quality of these streets as vital open spaces across the country. Furthermore, enhancing the quality of streets can help address a range of issues, such as dependence on cars, wellbeing, social interaction and cohesion, the image of a city, and environmental concerns.

\section{Literature Review}

The design quality of streets has been one of the most common subjects of research in the urban and planning field around the world. According to various studies, streets are not only for car movement but the design of streets can also enhance residents' daily lives and wellbeing and provide a positive image, as well as giving a city character (Carmona, 2019; Carmona et al., 2018; Lytvynenko et al., 2018). For example, the American movement "complete streets" emphasizes the importance of the design of streets for cars and also for all patterns of use and different users' demographics (Brown et al., 2016; Burden \& Litman, 2011; McCann \& Rynne, 2010; Geraghty et al., 2009). In addition, London has been investing in the quality of its streets to ensure a balance between circulation and places (Transport of London, 2019: 1).
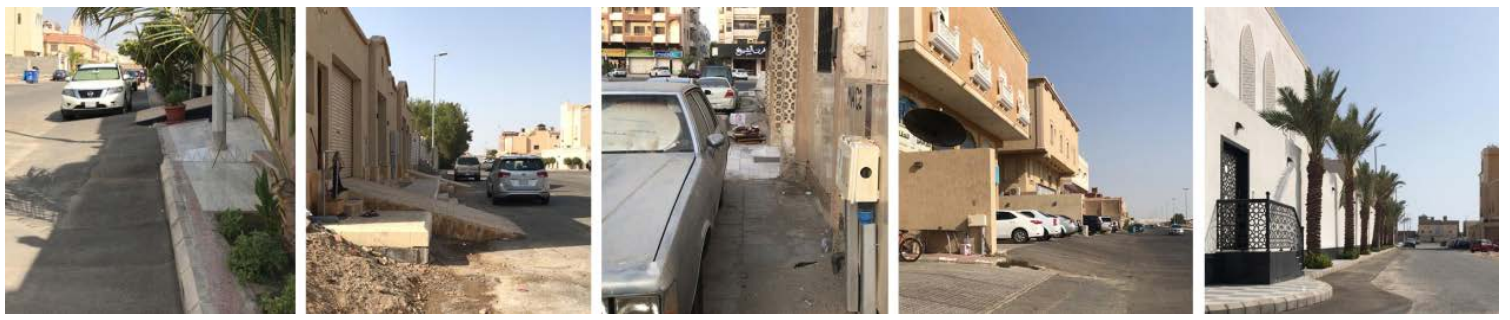

Figure 1. Examples of streets and sidewalks in Saudi Cities (source: Authors). 
Empirical urban planning studies have investigated residents' satisfaction with environmental quality (Smith \& Levermore, 2008; Van Kamp et al., 2003; Pacione, 2003; Chiesura, 2004; Rogerson, 1999; Amerigo \& Aragones, 1997). Amerigo and Aragones (1997) defined residential satisfaction as a "positive affective" of the individual mental experiences of residents of urban environments. The level of satisfaction is affected by objective and subjective environmental quality and the characteristics of the residents (Amerigo and Aragones, 1997).

Other empirical studies have identified how travellers gain satisfaction from street design (Eriksson et al., 2008; Fellesson \& Friman, 2008). Various studies have shown that people who are walking develop a sense of satisfaction based on a range of factors, such as air quality, planting design, hardscape design, and level of crowding (Stradling et al., 2007; Kim et al., 2014).

According to Jacobs (1996), liveability is the physical quality that is required of a great street, and it affects the use of the street. In Saudi Arabian cities, the concept of liveability has been neglected in recent years. Most streets are designed with priority for cars only (Figure 2); streets and sidewalks are not welcoming and do not accommodate all users' needs. Many streets are missing streetscape design elements, such as planting and signs, and many do not receive adequate maintenance (Figure 3 ).

Well-designed streets can increase civic engagement and social cohesion
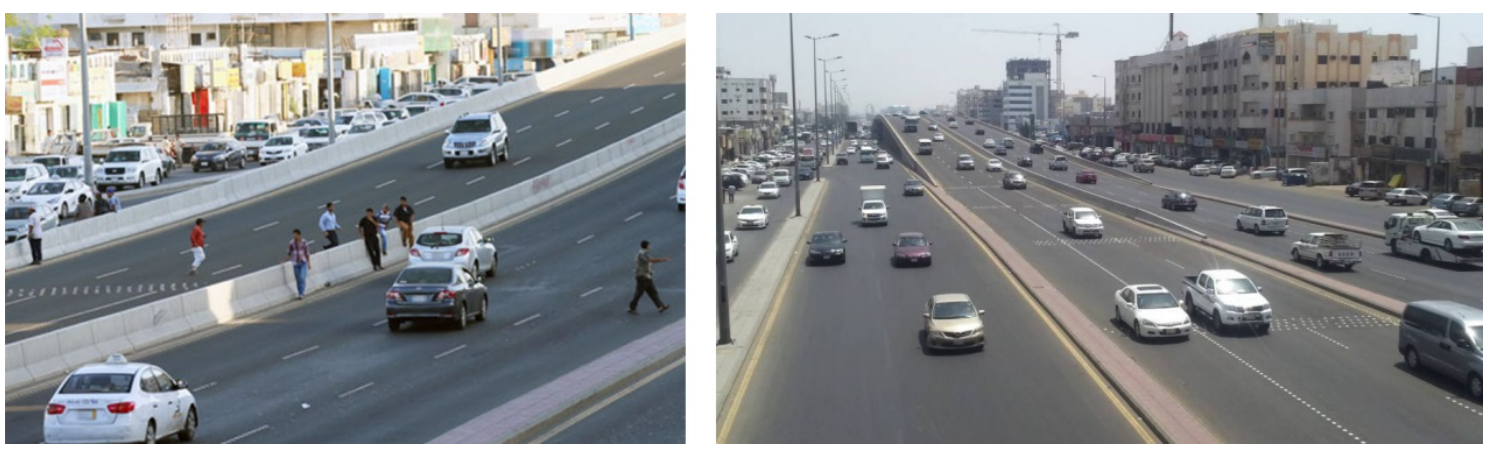

Figure 2. Saudi cities were designed for cars neglecting the pedestrian needs example from Prince Majid StreetJeddah (source: Authors).
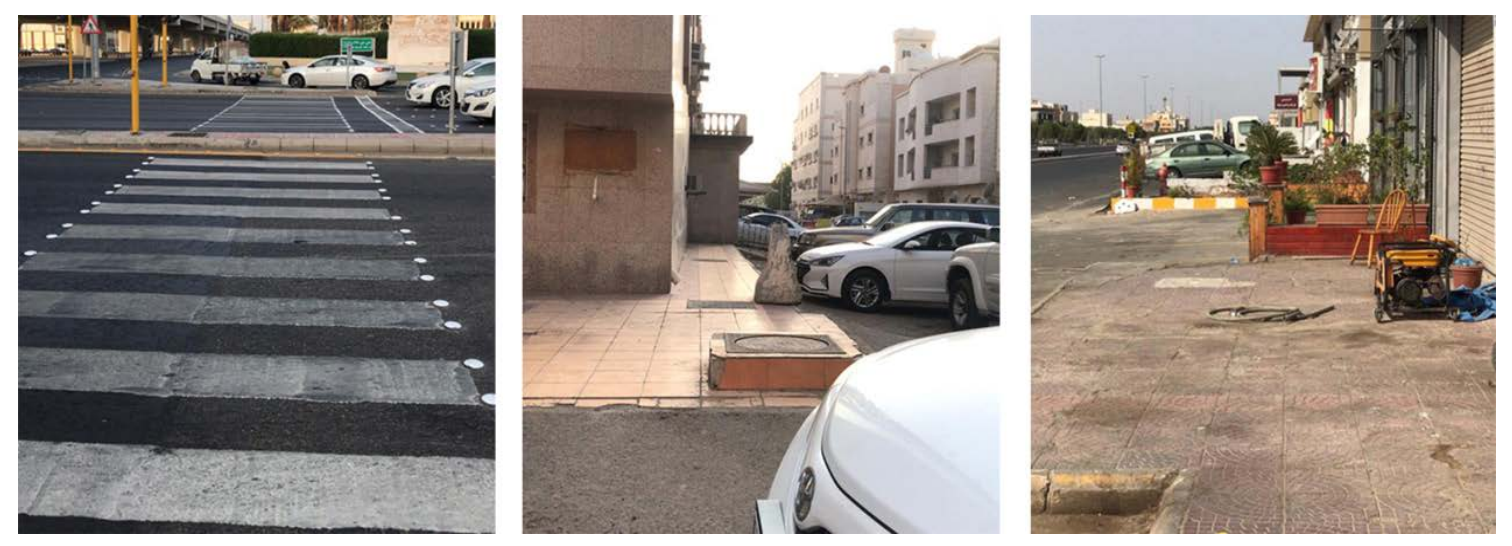

Figure 3. Streets in Jeddah lack of design, quality and maintenance Hera'a Street-Jeddah (source: Authors). 
(Hassen \& Kaufman, 2016), improve users' satisfaction (Jung et al., 2017), and directly affect residents' wellbeing (Spokane et al., 2007). In addition, a streetscape can play a role in the sustainability of the urban design (Rehan, 2013; Bandarabad \& Shahcheraghi, 2012; Greenberg, 2009).

According to Abdul Rahman et al. (2014), the users of streets are important because, without their interaction and activities, these streets will be without purpose. Activities are classified as essential activities (going to school or work, waiting or shopping), possible activities (walking, sightseeing, or sitting) and public activities (playing, gathering, watching events) (Abdul Rahman et al., 2014; Gehl, 2010; Turel et al., 2007). According to Gehl (2011), the quality of the spaces has a direct effect on users' perceptions and the patterns of use of the spaces (Gehl, 2011); this means that when the design value and quality of a street are considered, people will be motivated to use it more. Planners and designers must consider the typology of the street and try to design the streets according to its location (Shamsuddin et al., 2010; Davies, 2000).

Studies support the importance of creating comfortable streets for people to use and to interact with each other (Carr, 1992; Jacobs, 1996; Carmona et al., 2008). In hot countries, it is very important to consider the microclimate and establish spaces that are within the comfort zone of users (Carmona et al., 2008). Different landscape elements must be taken into account when making decisions on street design, including softscape, hardscape, and the use of structures such as shelters and pergolas (Mehta, 2014; Conn et al., 2010) (Figure 4).

\section{Methodology}

The research methodology was based on a theoretical and analytical approach, with an applied study of one of the streets of in Jeddah city. The theoretical study identified the importance of street design and streetscape elements and was followed by an analytical study of international experiences of the application of the principles and best practices of streetscape design. From the research, recommendations were developed for the selected site and generalized to help improve the quality of life in the urban environment in other Saudi cities.
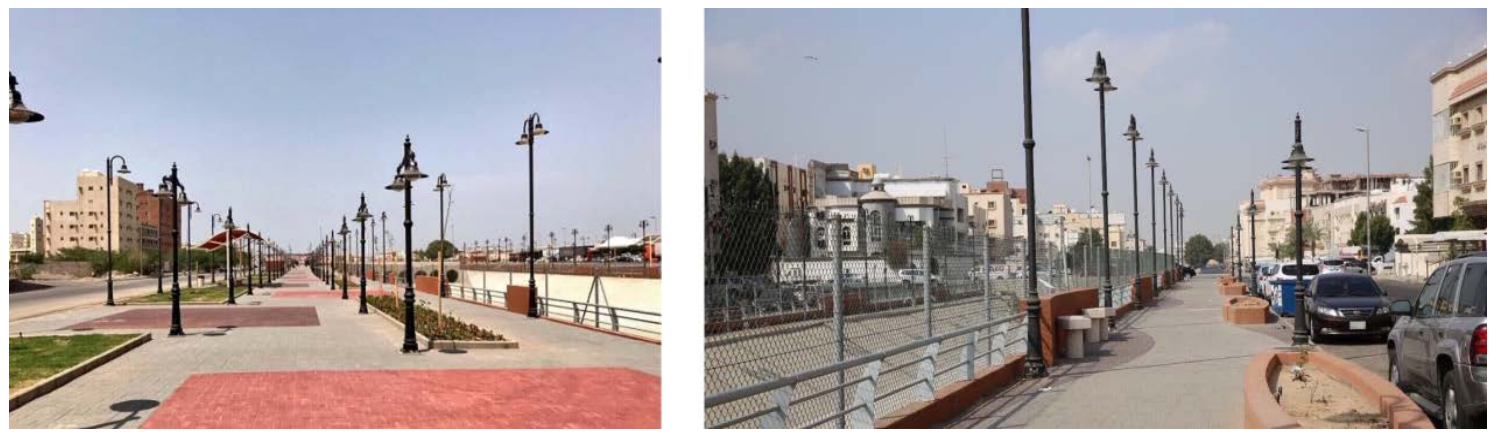

Figure 4. Lack of shade trees and other important streetscape elements and clear focus on lighting poles in both sides (source: Authors). 


\section{Case Study Site}

The survey and analysis of the street design highlighted the improvements that need to be considered during planning and design to enhance the quality of life in the street. Faisal bin Fahad Street is not far from the sea, and less than 300 metres from the new Jeddah Waterfront (Figure 5). The western part of the street is parallel to the Corniche road, which is separated by a group of residential high-rise buildings, hotels, residential complexes, a theme park and many empty plots of land. At the eastern end of the road, there is a linear development of residential and commercial villas, hotels, residential complexes, restaurants and empty land spaces. In the central median of the street, there is an open space consisting of seating areas, children's play equipment, and kiosks, as well as a walkway that is used for exercise and is a popular space in the city. This walkway was put in place in the early part of 2003.

The study area shown in Figure 6 was analysed to identify its strengths and potential areas of improvement. The study was carried out by conducting several visits and developing a planning map showing land use, building height and condition, and circulation (Figure 6). In addition, a visual study was carried out to identify high-use areas and amenities.

The analysis of Faisal bin Fahad Street revealed that the street lacks consideration of street design principles including safety, accessibility, and use of designed landscape elements. This finding suggests that quality of life and liveable streets principles are difficult to apply with the current planning and design approach to the streets (Addas, 2020). Furthermore, from observation of the study area, we noted that the street is facing high demand because of its location next to Jeddah Waterfront. The residents of the street suffer from visitors parking in front of
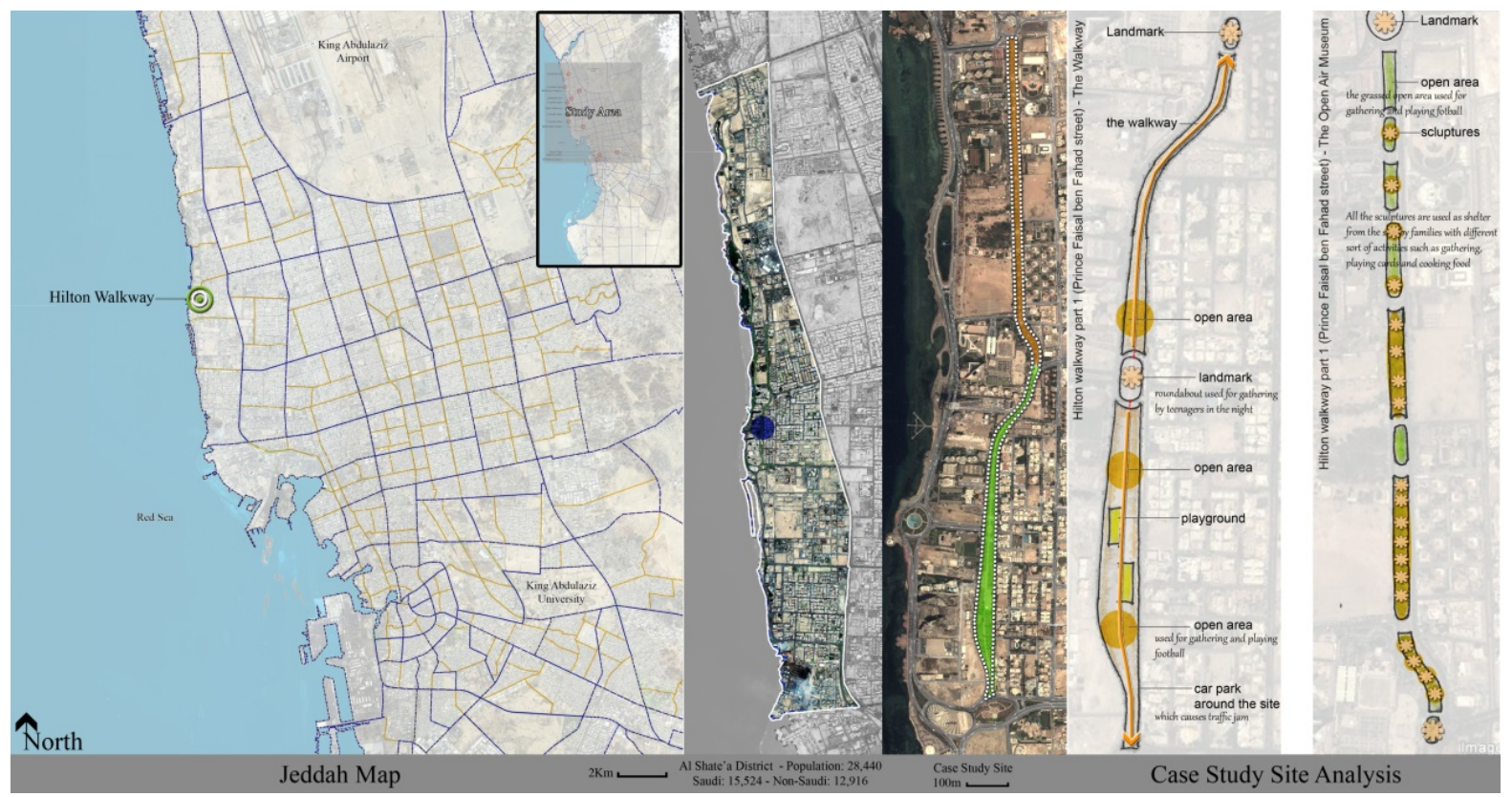

Figure 5. Study area location and space analysis (Prince Faisal Bin Fahad Street) (source: Authors). 
their homes because of the lack of parking facilities or public transportation systems, which would reduce car demand on the street. The central median, which is used as a public garden, is another high demand spot; however, this space was built randomly without being designed by specialists (Addas, 2015). As can be seen from the study area photographs, date palms have been planted in the central median where people exercise and walk, but these do not provide shade to the space.
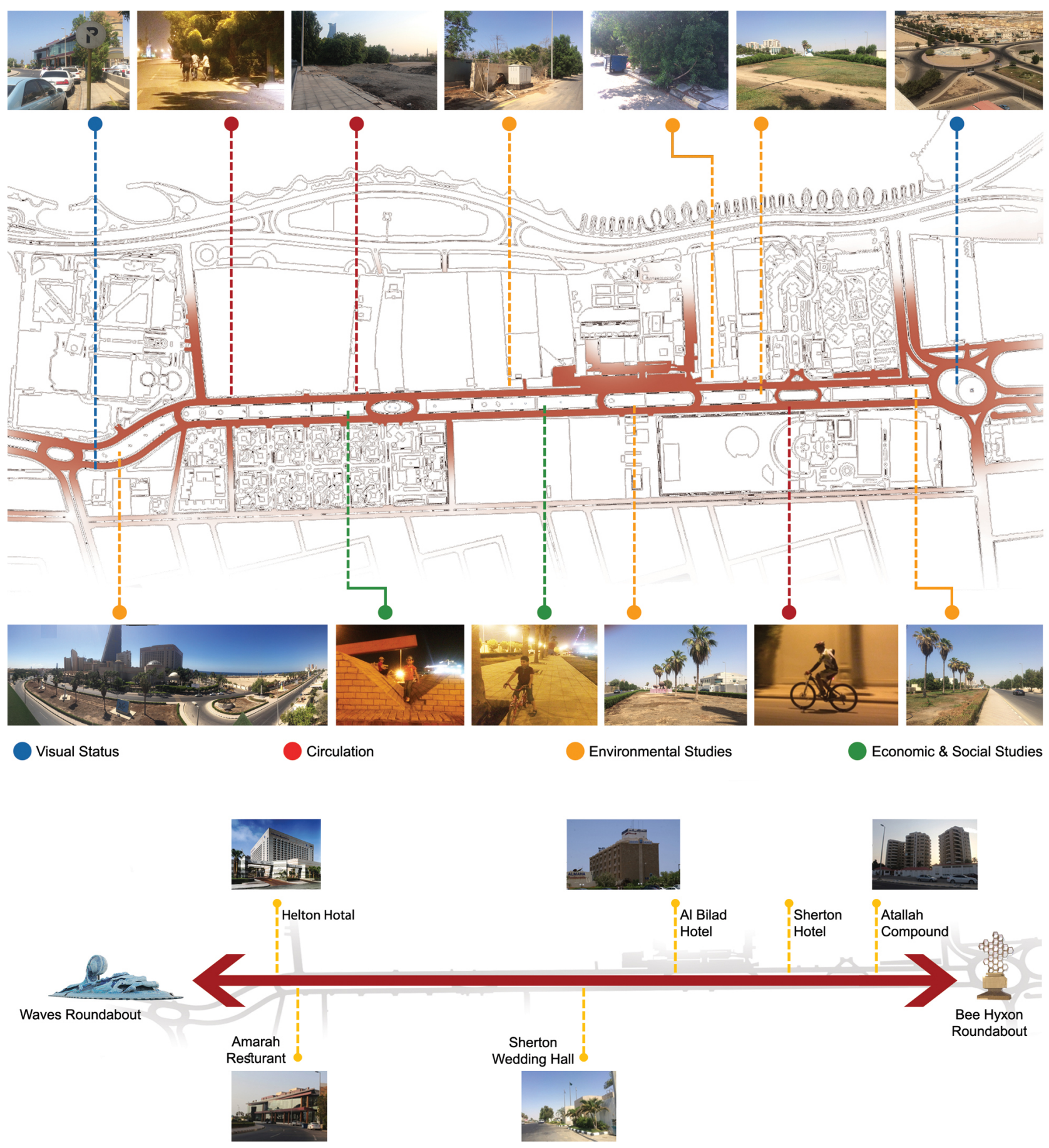


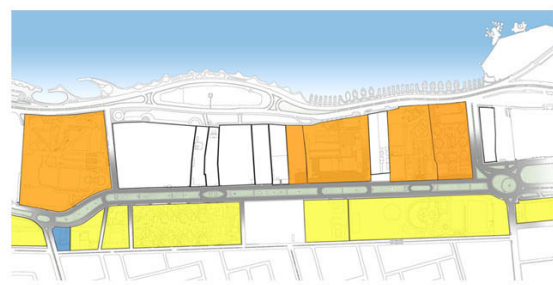

Land Use

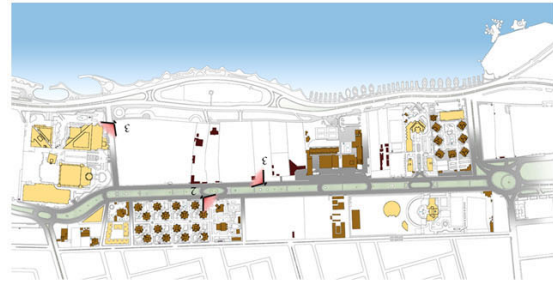

Buildings Condition

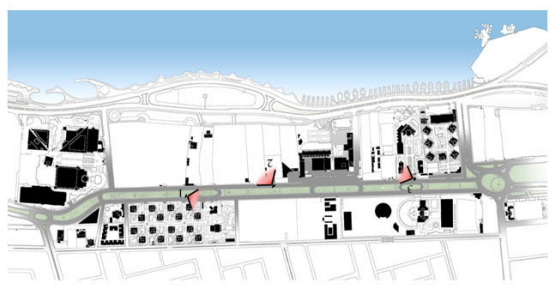

Solid \& Void

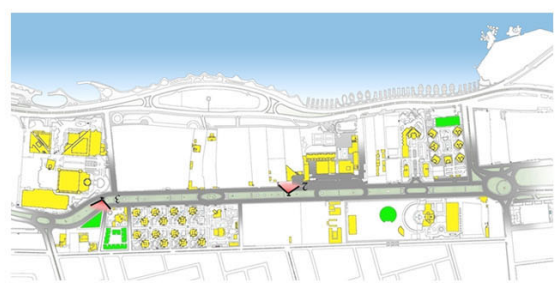

Buildings Ages

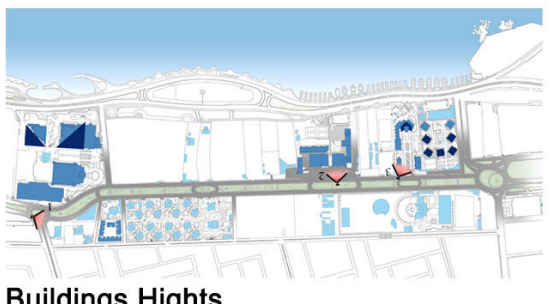

Buildings Hights

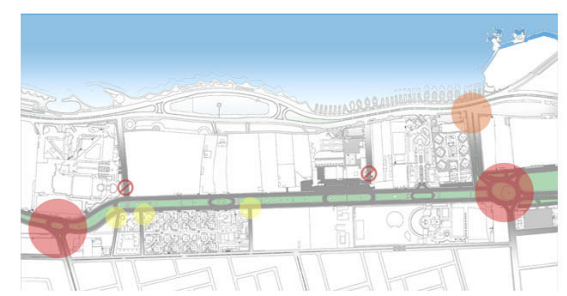

Axis Models

Figure 6. Study area analysis (source: Authors)

\section{Livable Street Recommendations}

To address the issues observed, MoMRA needs to create guidelines that developers can follow. In addition, a number of recommendations can be made to enhance the planning and design of streets like Faisal bin Fahad Street to enable them to become liveable streets. The following recommendations relate to the planning and design of the streets in Saudi Arabia:

\section{Users}

Understanding users' needs and patterns of using streets and outdoor spaces is very important during the planning and design of the urban and rural contexts. Planners and designers need to understand users' preferences and ensure that streets are designed to meet their needs and demands. In addition, extra consideration needs to be given to the special needs users, such as mothers with pushchairs, which are to some extent neglected in most of the cities.

\section{Aesthetics}

From the review of Jeddah streets, including the studied site, it was clear that the streets are not visually appealing because of the materials used, sign distribution, and lack of streetscape elements. In this regard, there is a need to create strict regulations for private owners on how to design and install shops signs and how to distribute commercial signs. There is also a need for a building code to control materials and characteristics and reduce the unattractiveness of the visual scene. Furthermore, streetscape elements should be given greater attention:

\section{Planting}

Plants can be used in different forms and for many functions. The use of a variety of plants of different types should be considered (palms, trees, shrubs, groundcover, climbers, and succulents). Palms are used heavily in the Saudi cities; however, these plants cannot provide shade, and there is a need to plant large trees in streets to make the streets more comfortable for walking even on warm days and to enhance visual appeal. MoMRA has a manual on how to 
use native species in urban contexts. There is a need to use native plants to reduce water consumption for irrigation, and rain gardens could be used to collect stormwater and recycle it for irrigation. In addition, the use of plants can help Saudi cities reduce the heat island effect in the future.

\section{Lighting}

There is a need to create a lighting plan and concept that provides different levels of lighting according to the street scale and activities. In addition, the use of solar-powered lighting sources can reduce demand for electricity.

\section{Site furniture}

Different streets and site furniture elements, such as signs, seats, and bins, must be selected carefully and matched together to offer identity and unity to the street such as many examples of urban design projects around the world. Furthermore, these elements must be managed and maintained periodically.

\section{Pavement}

Robust and durable materials should be used with variation according to the location and activities. Furthermore, the colors of the pavement must be selected carefully with the other selected street elements.

\section{Accessibility and walkability}

In addition to cars, different means of transportation should be taken into account when planning streets. To ensure that people can use the streets for walking or cycling, the streets and sidewalks must not have obstacles such as planters, trash bins, or electrical generators. Furthermore, the concept of walkability and connected streets at all levels should be considered during planning to ensure that streets are connected to activities and facilities on a neighborhood, district and city scale.

\section{Security and safety}

Laws and regulation must be applied in terms of crosswalks, and community awareness campaigns should be run to educate drivers on pedestrian safety. This will need careful planning of the street layout to identify suitable crossing points, bike lanes and pedestrian sidewalks. In addition, there is a need to design suitable barriers to separate pedestrians from traffic. The use of the central median as a public space must be forbidden because it affects peoples' safety and security.

\section{Activities}

There is a need to understand that streets are not only for movement; they are major public spaces in a city. This shift in perception will require an understanding of activities and different uses that streets can support according to their urban context.

\section{Conclusion}

The purpose of this paper is to identify approaches and recommendations to the planning and design of the streets in Saudi Arabia that would enable them to become liveable streets. From examining the study area, we found out the crite- 
ria for designing streets are neglected to some extent. The analytical study showed that there are planning issues in the study area. In particular, building public open spaces in the middle of the street is considered to be a major problem. Furthermore, streetscape elements are not designed or matched to create a positive image. This study established a set of recommendations based on the international literature which aim to enhance the quality of life in the streets in Saudi Arabia.

There is a need to build capacity in MoMRA and the municipalities in the planning and design fields. In addition, the current guidelines of MoMRA must address policies for planning and design in urban spaces, especially streets, and consider streetscape elements. Furthermore, streets must be given a pedestrian orientation by considering comfort, accessibility and safety. The microclimate for a hot country is an important issue that needs to be addressed when designing streets, with extra attention to the provision of native plants to reduce the water demand for irrigation. The findings from this study highlight the current situation of the streets in Saudi Arabia, and the main aim is to guide future development, planning and design of urban streets by providing recommendations which will help enhance the quality of life in the streets. Furthermore, there is a need to examine the impact of the street design on the users in Saudi cities to understand their perception and value of the streets.

\section{Conflicts of Interest}

The authors declare no conflicts of interest regarding the publication of this paper.

\section{References}

Abdul Rahman, N., Shamsuddin, S., \& Ghani, I. (2014). What Makes People Use the Street? Towards a Liveable Urban Environment in Kuala Lumpur City Centre. Procedia-Social and Behavioural Sciences, 170, 624-632. https://doi.org/10.1016/j.sbspro.2015.01.064

Addas, A. (2015). Motivation and Attachment in the Use of Public Open Spaces in Jeddah, Saudi Arabia. Unpublished PhD Dissertation, Sheffield: Landscape Department, the University of Sheffield.

Addas, A. (2018). Landscape Architecture and the Saudi Arabia Quality of Life Program. Emirates Journal for Engineering Research, 24, 21-29.

Addas, A. (2020). Enhanced Public Open Spaces Planning in Saudi Arabia to Meet National Transformation Program Goals. Current Urban Studies, 8, 184-204. https://doi.org/10.4236/cus.2020.82010

Almahmood, M., Schulze, O., Carstensen, T. A., \& Jørgensen, G. (2018). The Sidewalk as a Contested Space: Women's Negotiation of Socio-Spatial Processes of Exclusion in Public Urban Space in Saudi Arabia; the Case of Al Tahlia Street. Planning Practice \& Research, 33, 186-210. https://doi.org/10.1080/02697459.2017.1419652

Amerigo, M., \& Aragones, J. I. (1997). A Theoretical and Methodological Approach to the Study of Residential Satisfaction. Journal of Environmental Psychology, 17, 47-57. https://doi.org/10.1006/jevp.1996.0038 
Badawi, S. (2017). Sustainable Approach for Developing Local Mixed-Use Streets Case Study Beit Al Maqdis Street in Jeddah. Procedia Environmental Sciences, 37, 374-385. https://doi.org/10.1016/j.proenv.2017.03.003

Bandarabad, A., \& Shahcheraghi, A. (2012). Livable Street in Urban Environment: An Adaptive Design Approach. Advances in Environmental Biology, 6, 1063-1067.

Brown, B. B., Smith, K. R., Tharp, D., Werner, C. M., Tribby, C. P., Miller, H. J., \& Jensen, W. (2016). A Complete Street Intervention for Walking to Transit, Nontransit Walking, and Bicycling: A Quasi-Experimental Demonstration of Increased Use. Journal of Physical Activity and Health, 13, 1210-1219. https://doi.org/10.1123/jpah.2016-0066

Burden, D., \& Litman, T. (2011). America Needs Complete Streets. ITE Journal (Institute of Transportation Engineers), 81, 36-43.

Carmona, M. (2019). Place Value: Place Quality and Its Impact on Health, Social, Economic and Environmental Outcomes. Journal of Urban Design, 24, 1-48. https://doi.org/10.1080/13574809.2018.1472523

Carmona, M., de Magalhães, C., \& Hammond, L. (2008). Public Space: The Management Dimension (pp. 1-232). London: Routledge Taylor \& Francis Group. https://doi.org/10.4324/9780203927229

Carmona, M., Gabrieli, T., Hickman, R., Laopoulou, T., \& Livingstone, N. (2018). Street Appeal: The Value of Street Improvements. Progress in Planning, 126, 1-51. https://doi.org/10.1016/j.progress.2017.09.001

Carr, S. (1992). Public Space. Cambridge: Cambridge University Press.

Chiesura, A. (2004). The Role of Urban Parks for the Sustainable City. Landscape and Urban Planning, 68, 129-138. https://doi.org/10.1016/j.landurbplan.2003.08.003

Conn, S., Low, S., Taplin, D., \& Scheld, S. (2010). Rethinking Urban Parks: Public Space and Cultural Diversity. The Antioch Review, 64, 577. https://doi.org/10.2307/4615042

Davies, L. (2000). Urban Design Compendium, English Partnership UK.

Eriksson, L., Friman, M., \& Gärling, T. (2008). Stated Reasons for Reducing Work-Commute by Car. Transportation Research Part F: Traffic Psychology and Behaviour, 11, 427-433. https://doi.org/10.1016/j.trf.2008.04.001

Fellesson, M., \& Friman, M. (2008). Perceived Satisfaction with Public Transport Services in Nine European Cities. Journal of the Transportation Research Forum, 47, 93-103. https://doi.org/10.5399/osu/jtrf.47.3.2126

Gehl, J. (2010). Cities for People. Washington DC: Island Press.

Gehl, J. (2011). Life between Buildings: Using Public Space. Washington, DC: Island Press.

Geraghty, A. B., Seifert, W., Preston, T., Holm, C. V., Duarte, T. H., \& Farrar, S. M. (2009). Partnership Moves Community toward Complete Streets. American Journal of Preventive Medicine, 37, S420-S427. https://doi.org/10.1016/j.amepre.2009.09.009

Greenberg, E. (2009). Sustainable Streets: An Essential Emerging Practice. APA Planning Advisory Service Reports, 78, 73-84.

Hassen, N., \& Kaufman, P. (2016). Examining the Role of Urban Street Design in Enhancing Community Engagement: A Literature Review. Health and Place, 41, 119-132. https://doi.org/10.1016/j.healthplace.2016.08.005

Izenberg, J. M., \& Fullilove, M. T. (2016). Hospitality Invites Sociability, Which Builds Cohesion: A Model for the Role of Main Streets in Population Mental Health. Journal of Urban Health, 93, 292-311. https://doi.org/10.1007/s11524-016-0027-Z

Jacobs, A. B. (1996). Great Streets. Cambridge: The MIT Press.

Jung, H., Lee, S., Kim, H. S., \& Lee, J. S. (2017). Does Improving the Physical Street Envi- 
ronment Create Satisfactory and Active Streets? Evidence from Seoul's Design Street Project. Transportation Research Part D: Transport and Environment, 50, 269-279. https://doi.org/10.1016/j.trd.2016.11.013

Kim, S., Park, S., \& Lee, J. S. (2014). Meso- or Micro-Scale? Environmental Factors Influencing Pedestrian Satisfaction. Transportation Research Part D, 30, 10-20. https://doi.org/10.1016/j.trd.2014.05.005

Lytvynenko, T., Tkachenko, I., \& Ilchenko, V. (2018). Principles of Street and Urban Road Space Formation in Modern Cities. International Journal of Engineering \& Technology, 7, 642. https://doi.org/10.14419/ijet.v7i3.2.14606

McCann, B., \& Rynne, S. (2010). Complete Streets: Best Policy and Implementation Practices (pp. 1-143). APA Planning Advisory Service Reports No. 559.

Mehta, V. (2014). Evaluating Public Space. Journal of Urban Design, 19, 53-88. https://doi.org/10.1080/13574809.2013.854698

Moreland-Russell, S., Eyler, A., Barbero, C., Hipp, J. A., \& Walsh, H. (2013). Diffusion of Complete Streets Policies across US Communities. Journal of Public Health Management and Practice, 19, S89-S96. https://doi.org/10.1097/PHH.0b013e3182849ec2

Pacione, M. (2003). Urban Environmental Quality and Human Wellbeing-A Social Geographical Perspective. Landscape and Urban Planning, 65, 19-30. https://doi.org/10.1016/S0169-2046(02)00234-7

Rahman, M. T., \& Nahiduzzaman, K. M. (2019). Examining the Walking Accessibility, Willingness, and Travel Conditions of Residents in Saudi Cities. International Journal of Environmental Research and Public Health, 16, 545. https://doi.org/10.3390/ijerph16040545

Rehan, R. M. (2013). Sustainable Streetscape as an Effective Tool in Sustainable Urban Design. HBRC Journal, 9, 173-186. https://doi.org/10.1016/j.hbrcj.2013.03.001

Rogerson, R. J. (1999). Quality of Life and City Competitiveness. Urban Studies, 36, 969-985. https://doi.org/10.1080/0042098993303

Shamsuddin, S., Abdul Rahman, N., \& Sulaiman, A. B. (2010). How Walkable Is Our City? Its Influence in Creating Sustainable City Centre Design. In the International Conference Sustainable Architecture \& Urban Design. Malaysia: Universiti Sains Malaysia.

Smith, C., \& Levermore, G. (2008). Designing Urban Spaces and Buildings to Improve Sustainability and Quality of Life in a Warmer World. Energy Policy, 36, 4558-4562. https://doi.org/10.1016/j.enpol.2008.09.011

Smith, R., Reed, S., \& Baker, S. (2010). Street Design: Part 1 Complete Streets. Public Roads, 74 .

Spellman, C. (2008). Streetscape Handbook (pp. 14-52). Omaha: Omaha by Design.

Spokane, A. R., Lombard, J. L., Martinez, F., Mason, C. A., Gorman-Smith, D., Plater-Zyberk, E., Szapocznik, J. et al. (2007). Identifying Streetscape Features Significant to Well-Being. Architectural Science Review, 50, 234-245. https://doi.org/10.3763/asre.2007.5029

Stradling, S. G., Anable, J., \& Carreno, M. (2007). Performance, Importance and User Disgruntlement: A Six-Step Method for Measuring Satisfaction with Travel Modes. Transportation Research: Part A, 41, 98-106. https://doi.org/10.1016/j.tra.2006.05.013

Transport of London (2019). Streetscape Guidance London: Mayor of London. http://content.tfl.gov.uk/streetscape-guidance-.pdf

Turel, H. S., Yigit, E. M., \& Altug, I. (2007). Evaluation of Elderly People’s Requirements 
in Public Open Spaces: A Case Study in Bornova District (Izmir, Turkey). Building and Environment, 42, 2035-2045. https://doi.org/10.1016/j.buildenv.2006.03.004

Van Kamp, I., Leidelmeijer, K., Marsman, G., \& De Hollander, A. (2003). Urban Environmental Quality and Human Well-Being towards a Conceptual Framework and Demarcation of Concepts; a Literature Study. Landscape and Urban Planning, 65, 5-18. https://doi.org/10.1016/S0169-2046(02)00232-3

Watkins, R., Palmer, J., \& Kolokotroni, M. (2007). Increased Temperature and Intensification of the Urban Heat Island: Implications for Human Comfort and Urban Design. Built Environment, 33, 85-96. https://doi.org/10.2148/benv.33.1.85 